FIONA PRICE

\title{
Democratizing Taste: Scottish Common Sense Philosophy and Elizabeth Hamilton
}

While the importance of Scottish common sense philosophy to the political debates, which occurred in Britain at the end of the eighteenth century has been recognized, ${ }^{1}$ its complex influence remains little understood. Scottish common sense philosophy was not only connected with the rejection of 'Metaphysicks', as is often assumed, but was used to form constructive replies to radicalism. Further, in the attempt to find practical answers to the social debates of the 1790s, Scottish common sense philosophy made an advance on Romantic aesthetics. The influence of the Scottish Enlightenment meant that, while the language of the common man was important, the individual himself took on a new role as aesthetic judge. This is evident in the work of the self-confessed opponent to sceptical philosophy, Elizabeth Hamilton.

Critical commentary on Elizabeth Hamilton's work usually concentrates on her participation in the post-French Revolution debate. However, Hamilton's later work uses both common sense philosophy and the association of ideas in an attempt to find workable answers to questions about (self-) government raised by the political arguments of the 1790s. Hamilton's common sense criticisms of radical philosophers implied the overly imaginative nature of their work and connected their 'metaphysics' with the emptiness of fashion. In contrast, Hamilton adopted herself the common sense position that it was possible to make meaningful assumptions about the external world. This led her to argue that, in distinction to following the arbitrary associations of fashion, all individuals could be educated to possess a set of appropriate associations that would make them tasteful. Providing an alternative to what Hamilton saw as the trend for revolutionary philosophy, taste would in turn improve the community's health. 
In this assertion of aesthetic division, Hamilton's work also illustrates the importance of Scottish common sense philosophy to a particular rhetoric of Romantic aesthetics, outlined by Wordsworth in the 1802 preface to The Lyrical Ballads. ${ }^{2}$ Wordsworth separates texts, readers and events into two groups: on the one hand, there are works and readers defined by a 'degrading thirst after outrageous stimulation'; there is revolution, urbanization and growing consumerism. ${ }^{3}$ On the other, there are those works and readers connected with a supposedly more natural and permanent set of associations. Importantly, Elizabeth Hamilton's work illuminates Wordsworth's position by showing a clear progression from the common sense suspicion of scepticism, revolution and fashion to the development of an associationist, romantic aesthetic. In addition, relying on common associations, Hamilton's version of taste rewrote older accounts of taste, in which aesthetic judgement was an exclusive quality, possessed by the upper ranks and indicative of their ability to rule. Hamilton's work demonstrates how Scottish common sense philosophy and the post-French Revolution debate created the demand for a new, and potentially radical, democratic account of taste.

The sophistication of Hamilton's work calls for a critical re-evaluation of the notion that Scottish common sense responses to radicalism were 'simple' rejections of theory unimportant to the development of Romantic aesthetics. Since Marilyn Butler's study Jane Austen and the War of Ideas (1975), a great deal of critical attention has been given to the 'quixote-like' hero of conservative novels, who is said to be 'deluded by [the] revolutionary ideas' of the 1790s. ${ }^{4}$ However, when examining attacks on the 'New Philosophy', critical commentators often accepted at face value the conservative writers' propagandist rejections of theory. ${ }^{5}$ Conservative novels, it seemed, attacked radical 'theory' without having either any sophisticated philosophical underpinnings of their own or any relevance to Romantic aesthetics. ${ }^{6}$ A challenge to this trend was offered by David Simpson's Romanticism, Nationalism, and the Revolt against Theory (1993), which historicized the conservative rejection of theory. ${ }^{7}$ It became clear that, in many cases, the Scottish common sense tradition founded by Thomas Reid formed the intellectual background to conservative criticisms of the 'New Philosophy' and was an important influence on Romanticism.

Nonetheless, the range and sophistication of its uses remained in doubt, partly because of confusion surrounding the term 'common sense'. ${ }^{8}$ Both radicals and conservatives used the expression, but the philosophical strategies of radicals such as Wollstonecraft differed from those of the conservative writers. Radicals frequently appealed to a 'common' reason, 
but, when used by conservatives, the Scottish common sense tradition could be a powerful weapon against the 'New Philosophy'. Its insistence on a knowable external world formed a useful counterargument to the perceived solipsism of those polemicists who wished to break with tradition. In addition, for those uncomfortable with Edmund Burke's account of tradition as a basis for government, it provided an intellectually credible option. ${ }^{9}$ An alternative to following precedent, the common sense insistence on shared knowledge of the external world underpinned the Romantic conception of nature as both aesthetic standard and ethical guide.

The progression from philosophy and politics to aesthetics is evident in the work of Elizabeth Hamilton. Her initial satires on the incorrect associations of sceptics in Letters of a Hindoo Rajah (1796) and Memoirs of Modern Philosophers (1800) had their basis in common sense philosophy. Significantly, however, Hamilton also subverted the radical attack on the corrupting influence of fashion. Instead, Hamilton argued that it was the sceptical philosophers who were subject to the random associations of fashion, to which she attempted to provide a more credible alternative. The result was a common sense account of taste in which the associations produced by nature had an important ethical role. In The Cottagers of Glenburnie; A Tale for the Farmer's Ingle-nook (1808) and A Series of Popular Essays (1813) Hamilton argued that a shared standard of taste could be developed through the emotional associations produced by nature. This would then promote more moral behaviour and provide a vital defence against both radical philosophy and unthinking adherence to tradition. ${ }^{10}$

\section{Common Sense, Hume and Elizabeth Hamilton: \\ THe DANGERS OF IMAGINATION}

According to Thomas Reid, David Hume's Treatise of Human Nature (1739) 'built a system of scepticism, which leaves no ground to believe any one thing rather than its contrary'. ${ }^{11}$ With a hint of the religiosity typical of common sense philosophy, Reid explained the disastrous results of such scepticism:

Absolute scepticism is not more destructive of the faith of a Christian, than of the science of a philosopher, and of the prudence of a man of common understanding. I am persuaded, that the unjust live by faith as well as the just; that, if all belief could be laid aside, piety, patriotism, friendship, parental affection, and private virtue would appear as ridiculous as knight-errantry. ${ }^{12}$

Reid rejected scepticism on the grounds that he thought that certain 
common conclusions, drawn about ourselves and our relation to the environment, were obviously correct. He argued that 'the natural faculties, by which we distinguish truth from error, are not fallacious' and consequently hoped to promote 'a view of the human understanding' different from that provided by 'Des Cartes, Malebranche, Locke, Berkeley', and the most notorious target of his attack, 'Hume'. ${ }^{13}$

Both Thomas Reid's arguments against David Hume, and his vocabulary, influenced conservative satirists in the post-French revolution debate who commonly applied them to the 'New Philosophy'. Accordingly, they associated the 'New Philosophy' with atheism, revolutionary principles and the rhetoric of romance, portraying both sceptics and radicals as overly imaginative. In addition, however, their common sense anxiety about how evidence from the external world could be verified and interpreted gave impetus to a growing interest in education. Hamilton exemplifies both reactions. Her satirical works Translation of the Letters of a Hindoo Rajah and Memoirs of Modern Philosophers develop the common sense debate with Hume into a concern with the imaginative processes of metaphysicians; in her account the weakness of their reasoning leaves them vulnerable to following intellectual fashion. However, it was Hamilton's resultant interest in the development of the human mind that led to her educational theory of taste.

One of the greatest differences between Hume and the common sense philosophers, and the most significant for Hamilton, was the treatment of the association of ideas. ${ }^{14}$ Hume argued that the imaginative power of association leads us to suppose that we see cause and effect in the external world, while all we can really perceive is contiguity and succession. ${ }^{15} \mathrm{In}$ making this claim, Hume used association to question several principles which Reid insisted were self-evident. Overall, the implication was that conclusions about the external world relied on the imagination and might not be particularly accurate. This emphasis on the imagination meant that, for Hume, the individual's judgement was rendered vulnerable, his opinions easily subject to distortion by others because of difficulty in verifying their value. Hence, although Hume put considerable stress on sympathy - an ability to associate emotionally with others - he was concerned to protect the individual from the pressures and opinions of the social group. His sympathetic communities were always under erosion by his concern for privacy and independence, a concern that Reid and Hamilton saw as potentially solipsistic. Hume's unease about both the integrity and the value of the individual's judgement is particularly evident in his essay 'Of the Standard of Taste'. He initially signalled the importance of sympathy to taste by publishing the essay in Four Dissertations (1757), 
which began with 'On the Passions'. ${ }^{16}$ However, in the latter half of 'Of the Standard of Taste', sympathy becomes far from sufficient. There, Hume sets up a series of tests for the individual judgement, requiring in his critic 'practice in a particular art', the ability to make 'comparisons ... examin[ing], and weigh[ing] the several performances, admired in different ages and nations', and a removal of 'prejudice'. This last involves a knowledge of others' 'peculiar views and prejudices' - a kind of education in international art, which in turn gives the perspective to remain detached. ${ }^{17}$ Elsewhere, Hume even suggests that suspicion and antagonism are desirable in encouraging good taste since they will prevent the 'contagion of popular opinion'. ${ }^{18}$

In response, common sense philosophers tried to make the association of ideas fit their own picture of the human mind: they resisted the notion that their beliefs were based solely on imagination and consequently vulnerable to fashion. Anxious about mental development, George Campbell, for example, argued that our assumptions about the external world were not based solely on imagination. On the contrary, memory and association were reliable sources of information both when making judgements about the external world and when reasoning about morals. ${ }^{19}$ According to Campbell, 'Moral evidence is founded on the principles we have from consciousness and common sense, improved by experience' while 'experience' consists of 'retention and association'. ${ }^{20}$ In Campbell's account, 'this kind of reasoning in its earliest or simplest form' seems more-or-less instinctive since 'little or no reflection is necessary ... Every man will be ready to tell you, that he needs no other witnesses than his eyes, to satisfy him that objects are not in contact with his body, but are at different distances from him as well as from one another. So passive is the mind in this matter ...'. This form of reasoning is particularly evident in childhood and is the most reliable: 'It is true, indeed, that the conclusions in the first way, by which also in infancy we learn language, are commonly more to be regarded as infallible, than those effected in the second. ${ }^{21}$ For Campbell the second stage in which associations are more obviously learnt is a source of unease because the conclusions we reach are no longer 'infallible' but subject to error. His sudden introduction of the topic of childhood into the discussion is suggestive, however, since it opens up the possibility of the kind of education through association which John Locke and David Hartley had described. In the common sense account correct education would produce the necessary memories and associations to ensure truly correct judgement on which everyone might agree.

This philosophical debate over the development - and reliability - of the human mind contributed to the increasing politicization of education. 
In the increasingly volatile climate of the 1790 s, both radicals and conservatives realized the importance of education to their competing social visions. Educational theories based on the work of Locke and Hartley were employed by dissenters including Richard Price and Joseph Priestley, and later William Godwin, for politically progressive ends. These tended to emphasize independence. In contrast, other commentators took a common sense approach and stressed the helpfulness of shared knowledge. Hijacking Hume's emphasis on the imagination, they argued that it was the sceptics and the radical philosophers and teachers who were subject to overly active imaginations. Elizabeth Hamilton, in particular, initially attacked the potential solipsism of the 'New Philosophy' and its vulnerability to fashion, before developing an alternative theory of taste based on shared associations.

Although Elizabeth Hamilton recalled reading Lord Kames's associationist work, Elements of Criticism (1762) as a young girl, her interest in philosophical controversy can be traced to the publication of her first novel, Translation of the Letters of a Hindoo Rajah (1796). ${ }^{22}$ This satiric critique of Eastern and Western values contained a lengthy parody of 'Philosophers[s]', who, instead of being men '“deep in knowledge either moral or natural", were ignorant individuals, 'entertain[ing] a high idea of their own superiority, from having the temerity to reject whatever has the sanction of experience, and common sense'. ${ }^{23}$ In the novel's most grotesque episode, a young 'Sceptic' decides to prove 'that sparrows may be changed into honey-bees' by altering the 'external circumstances', thereby killing hundreds of 'nestlings'. ${ }^{24}$ In a letter to Mary Hays, who was annoyed at the novel's attack on Godwin, Hamilton claimed that such instances of philosophical 'absurdity' were extremely common:

In my opinion it is a strange sort of a compliment you pay your friend Mr Godwin, in taking it for granted that he has made a Monopoly of all the absurdity, and extravagance in the world; and that it is impossible to laugh at any thing ridiculous without pointing at him. Ignorant as I am, and ignorant as to the world you have declared me to be, I could point out to your perusal volume upon volume where you might see in the regions of Metaphysicks fancy has taken as bold a flight and that in the rage for systemizing are those of at least as distinguished eminence have laid themselves open to ridicule. ${ }^{25}$

Her remark about the 'systemizing' tendencies of her opponents reflects the typical common sense suspicion that sceptical philosophers constructed elaborate theories not supported by empirical evidence - it was because they were overly imaginative and ignored the evidence of 
common sense that they came to inaccurate conclusions about the external world. To this common sense observation Hamilton adds an attack on fashion. She suggests that metaphysicians, following a 'rage' in current philosophy as others might in dress, are 'extravag[ant]'; fashions of both sorts lead individuals to put an incorrect or distorted value on what they see. In radical accounts, such as Wollstonecraft's, the weakness of blindly following fashion belongs to those entrenched in the existing order, women, of course, but, more significantly, priests and soldiers. ${ }^{26}$ Hamilton moderates this rhetoric by suggesting that radical philosophers who have 'no ground to believe any one thing rather than its contrary' are equally vulnerable to the unruly associations that characterize fashion.

Elizabeth Hamilton states this at greater length in Memoirs of Modern Philosophers (1800), where the seducer and false philosopher, Vallaton, not only changes his opinion according to his convenience but previously had 'the task of adorning the heads of his fair country-women'; fashion and philosophy are again intimately connected. ${ }^{27}$ Throwing away the prejudices of tradition, Hamilton argues, the sceptics come to rely, not on the independent reason they champion, but upon idle and changing trends which make them look at worst vicious or at best foolish. Brigetina, for example, who is interested in 'cowsation and perfebility', as her mother puts it, wears a 'blue gown and yellow slippers', a wig and 'stiff turban and gaudy ribbons' in a mistaken attempt to look attractive. ${ }^{28}$ Arbitrary associations fill her mind, and her appearance connects intellectual with aesthetic weakness. Parodying Godwin's Enquiry Concerning Political Justice (1793), his Memoirs of the Author of 'A Vindication of the Rights of Woman' (1798), and Hays's Memoirs of Emma Courtney (1796), the book was Hamilton's greatest success. ${ }^{29}$

However, Hamilton was not content with merely attacking those philosophers she associated with Hume's scepticism; she wished to counter the influence of the 'modern philosophers'. She therefore developed a theory of education which relied upon the association of ideas. In this account, commonly held associations, based on accurate observation of the environment, could form a basis for a more moral and, supposedly, more accurate taste. From Hamilton's common sense perspective this taste would not merely be a matter of individual preference but would be widely agreed upon because of its basis in accurate assumptions about the external world. Her interest in the uses of association was visible in her next work, Letters on Education. There Hamilton echoed Reid by insisting that 'rules are less necessary than principles'. ${ }^{30}$ In his Inquiry into the Human Mind (1764), Reid had written that while mechanics, astronomy and optics had rules which could 'universally obtain', rules for the mind would 
not work. Instead, Reid maintained a belief in 'certain principles' of 'common sense', pp. 9-10, 32). By defending these principles, he attempted to provide a philosophical alternative to scepticism; in contrast, Hamilton's alternative was educational. Having made the case for the harmful effects of a sceptical or 'systematizing' education in her novels, in her pedagogic writings Hamilton argued that the flexibility of principles rather than rules was necessary, if the developing mind was to be trained successfully. To exemplify this, she gave the example of an agricultural improver who, instead of indiscriminately employing on the Grampian Hills the system of rules put down by the Devonshire farmer, adopted a more practical, flexible approach to theory, using general principles. ${ }^{31}$ With this reference to farming, Hamilton signalled that her position was as down to earth - as unextravagant - as the soil itself. In contrast, she implicitly compares the sceptical philosophers to 'improvers' such as Repton and Brown, whose fashionable theories of landscape management neglected the local and particular in favour of generalization. Like the over-zealous agriculturist, Hamilton implied, the so-called systematic New Philosopher does not inquire into particular circumstances but places an incorrect value on what he sees - his systems are inflexible, failing to respond to empirical stimuli. She, on the other hand, wishes to use the principles of associationist psychology, drawing upon what people commonly observe and experience to stabilize the social group. In A Series of Popular Essays and her last novel, The Cottagers of Glenburnie, Hamilton argued that associationism could be used to avoid the folly and violent stimulation of fashion and generate a correct taste, which would ultimately transform the whole community.

\section{The Cottagers of Glenburnie and A Series of Popular Essays; Philosophical Accounts of Taste}

Like William Wordsworth's remarks on the 'real language of men', the titles of both Elizabeth Hamilton's last novel, The Cottagers, and her Popular Essays signal a rejection of fashion in favour of something apparently more generally accessible. ${ }^{32}$ In arguing that taste was essential for everyone, Elizabeth Hamilton was pursuing what had been for the discourse of taste an unusually democratic line. Daniel Cottom has argued that the eighteenth-century discourse of taste frequently constructed aesthetic judgement as an exclusive possession, enjoyed by the upper ranks. ${ }^{33}$ It was also connected, through the discourse of civic humanism, with the ability to wield political power. When Sir Joshua Reynolds wrote that 'musick is said to have had its origin from a man at leisure listening 
to the strokes of a hammer' he captured an important truth about eighteenth-century manifestations of taste. ${ }^{34}$ In this discourse, for there to be tasteful people, there must be those (the majority) without taste. Taste, particularly in terms of the eighteenth century, is thus an aristocratic discourse, one requiring qualifications, particularly connoisseurship, not generally available. ${ }^{35}$ Specifically, Reynolds's listener requires leisure and, in turn, his leisure and detachment grant him greater authority and judgement than the artisan. He is more fit to rule.

A reaction to the French Revolution, the Romantic suspicion of fashionable excess contained a potential threat to this exclusivity. It became increasingly difficult to argue that the supposed taste possessed by the upper ranks was a secret, unavailable to the majority, or that it represented their innate right to rule. Instead, it became evident that the rest of society followed the trends started by the higher orders, giving a misplaced value to the consumer choices of the privileged. In Elizabeth Hamilton's account, both the fine ladies who aped their betters, and the philosophers who chased intellectual trends were, like David Hume, followers of fashion - driven by their imaginations to incorrect conclusions and prone to neglect the evidence of their senses. Given that this was seen as socially pernicious, an alternative had to be provided. For commentators such as Wordsworth and Elizabeth Hamilton it was necessary to distinguish fashion from genuine aesthetic judgement. Wordsworth's desire to reform poetic language on that used in rustic life is one such manoeuvre. Elizabeth Hamilton's narrative of aesthetic improvement was another, explicitly aimed at the aesthetic life of both the middle and lower class. Hamilton's biographer, Elizabeth Benger, suggests the project's success by giving the anecdote of an old woman making a profit by hiring out her copy of the novel to fellow villagers at $1 \mathrm{~d}$. a time. ${ }^{36}$ Hamilton's account of taste in the novel connected it, as will be shown, not with the incorrect associations of fashion but, as she saw it, with a more genuine attention to the comfort and emotions of others which is applicable in every social class. To this discussion of taste Hamilton's Popular Essays lends a philosophical dimension rather more explicit than that provided by Wordsworth's description of 'philosophical language' in the Preface. ${ }^{37}$ Hamilton's common sense approach and reaction to Hume allowed her to use the association of ideas to argue for a shared taste which would guarantee the health of the whole community.

Hamilton's novel, The Cottagers of Glenburnie, provides a fictional model of this inclusive process. The work begins with a description of the visit of its unconventional heroine, spinster and former servant, Mrs Mason, to Glenburnie. Mrs Mason, who shares her name with the instruc- 
tress in Wollstonecraft's Original Stories $(1788),{ }^{38}$ visits the middle-ranking Stewarts before travelling to Mrs MacClarty's cottage. Mrs MacClarty (the name means 'dirty') lives in a house which is both unattractive and disregarded, exhibiting a lack of taste and personal responsibility also evident even in the actions of the youngest children. Jean and her brother throw mud at the windows after Mrs Mason has cleaned them, reflecting the MacClarty family's strange mixture of fashionable aspirations and inattentiveness. Mrs MacClarty prevents her children learning household chores, arguing that 'they have not been used to [wark]'. She is more concerned that her children have the leisure enjoyed by the upper ranks than with the immediate comfort of the household. ${ }^{39}$ Most significantly of all, this lack of consideration is connected with a form of mistaken 'taste' that places prestige above utility, an error demonstrated in the most trivial of domestic incidents - supplying refreshments to weary visitors:

Miss Mary Stewart took upon herself the trouble of making tea, and began the operation by rincing all the cups and saucers through warm water; at which Mrs MacClarty was so far from being offended, that the moment she perceived her intention, she stepped to a huge Dutch press, and having, with some difficulty, opened the leaves, took from a store of nice linen, which it presented to their view, a fine damask napkin, of which she begged her to make use.

'You have a noble stock of linen, cousin,' said Mrs Mason. 'Few farmers houses in England could produce the like; but I think this is rather too fine for common use.'

'For common use!' cried Mrs MacClarty; 'na, na, we're no sic fools as put our napery to use! I have a dizen table-claiths in that press thirty years old, that were never laid upon a table. ${ }^{40}$

Mrs MacClarty presumably thinks this linen improves her status, but it does nothing to make her life easier, more comfortable or more enjoyable. In order to wipe the crockery tea drinkers use 'a long blackened rag', aesthetically unpleasant and unhygienic. ${ }^{41}$ Hamilton implies that it is foolish to think good taste means owning objects which are prestigious but neither useful nor ornamental - the fact that the dresser holding the napkins opened 'with some difficulty' underlines their impracticality.

In contrast to Mrs MacClarty, those who have good taste have an accurate view of the value of objects in their environment. This is emphasized in the second half of Mrs Mason's stay in Glenburnie, when her attempts at teaching the MacClarty children are contrasted with her fruitful endeavours with the Morisons. An unsuccessful tradesman, Mr Morison lost his 
money by 'extravagan[ce]', going into debt for fashionable objects of no direct use to his family. Educated by Mrs Mason, however, he learns to improve his situation by valuing objects in proportion to the genuine comfort they provide. As a schoolteacher he subsequently disseminates these values, and the result is an improvement in the comfort and beauty of the whole village. After Morison's efforts, the 'bright and clear glass of the [schoolhouse] windows, was seen to advantage peeping through the foliage of the rose-trees and other flowering shrubs that were trimly laid against the walls' ${ }^{42}$ This newly found cleanliness and taste, presumably the result of the school children's labours, contrast with the dirty windowpanes earlier in the novel. The children's early act suggests an inability to perceive the external world reminiscent of Hamilton's criticisms of the 'New Philosophers'. In contrast, the newly-cleaned glass promoted by the now rational associations of the schoolmaster suggests the common sense position that it is possible to make accurate judgements about the environment. Reid had argued that 'the natural faculties, by which we distinguish truth from error, are not fallacious'; Hamilton's account moderates this, positing that the correct operations of these 'natural faculties' are best ensured by sensitivity to the emotions of others and to the environment. Such sensitivity promotes correct vision by forming associations built upon the genuine comfort of others.

Reflecting Elizabeth Hamilton's emphasis on the importance of taste to the whole community, Glenburnie presents this emotionally responsive taste as equally important to the lower and middle classes. As Hamilton's discussion of dress indicates, each class is vulnerable to the associations of fashion and requires protection to ensure social harmony. Indicating that they value prestige more than comfort, the village girls of Glenburnie veer between the extremes of weekday squalor and Sunday finery. However, in the middle-class environment of the rectory Miss Stewart, the eldest daughter, also aspires to gentility. Aspirational but displaying a sad lack of financial acumen, she describes young ladies being fashionable: 'I don't mean those who have fortunes, for there is nothing in that; but those who have not a shilling to depend on. Yet they are all so fine' ${ }^{43}$ Miss Stewart's admiration is reserved for girls who go into debt for their finery; fashion, it would seem, inspires financial mismanagement. However, Hamilton argues that the circle of fashion and debt can be broken. With a tractability more often displayed by fictional than actual adolescents, Hamilton's village girls are re-educated in Glenburnie's new school, and no longer subscribe to extremes of weekday grime and Sunday best. Rather than pursuing fashion, they become perpetually neat. This benefits the community's appearance, its morality and, most importantly, its stability: 
the school girls' 'improvement in personal neatness and good-breeding' guaranteed 'the attention they were likely to pay to the instruction of their teacher in points still more essential. ${ }^{44}$

In policing the boundary between the random associations of material and intellectual fashion and the supposed emotional order of her own taste, Hamilton comes to a radical conclusion. Her emphasis on emotional education leads her to reject the position, popular throughout most of the eighteenth-century, that taste depends upon a connoisseurship characteristically possessed by the upper ranks. Instead, in The Cottagers of Glenburnie, Mrs Mason, viewing the Scottish countryside, values nature above art, the 'works of God' above those of man:

What are all the works of man, what all the pomp and splendour of monarchs, compared with the grandeur of such a scene? But the sights that are designed by man, as proofs of his creative skill, are only to be seen by the rich and great; while the glorious works of God are exhibited to all.Pursuing this thought a little farther, it occurred to Mrs Mason, that all that is rare, is in general useless; and that all that is most truly valuable is given in common, and placed within the reach of the poor and lowly. ${ }^{45}$

Mrs Mason's values here build on those set up elsewhere in Glenburnie. Having established that emotional sensitivity and the ability to make the right associations rely on the assessment of an object's direct utility, she dismisses the 'rare' art objects. Although these are possessed by the upper ranks and consequently fashionable, they remain, like Mrs MacClarty's linen, ultimately useless, only serving to inspire pointless emulation in the lower ranks. The natural objects which gave Mrs Mason so much pleasure, on the other hand, are 'truly valuable', that is, both useful and, by extension, representing a genuine grandeur or sublimity. Hamilton's insistence that the aesthetic appreciation of nature is connected with moral and spiritual health is typically Romantic. Her criticisms of high art are similar to, though perhaps more extensive than, Wordsworth's rejection of 'sickly and stupid German Tragedies, and deluges of idle and extravagant stories in verse'.$^{46}$ However, Hamilton does not want aesthetic education to be limited by acquaintance with relatively rare cultural objects of any sort. Instead, she extends the opportunity for correct aesthetic judgement by basing taste on common emotional associations.

In her Series of Popular Essays Elizabeth Hamilton explains her need to make taste inclusive; she also explains, in a way reflective of common sense philosophy, how such a widely available sense of taste is not merely 
a matter of personal opinion, but based on shared associations. The Essays were dedicated to Archibald Alison, whose Essays on the Nature and the Principles of Taste (1790) was one of the most completely associationist accounts given of the faculty. ${ }^{47}$ While Alexander Gerard and Lord Kames employed associationism to support neoclassical standards, Alison argued that personal associations triggered the emotion of taste. Hamilton uses similar terminology in order first to personalize taste and then to exploit it for her moral agenda. Hamilton refers to the 'emotions' of the sublime and the beautiful and emphasizes the importance of the individual's associations in facilitating such experiences: 'In order to excite that emotion [of beauty], the object must recall to our recollection some pleasurable feelings or sensations formerly experienced. ${ }^{48}$ Her interest in making taste more personal and thereby more widely available quickly becomes evident. Taste is, she says, 'seen as connected with the moral principle, and appears, not indeed as an additional faculty bestowed on a few fortunate individuals, but as an operation of the mind, to which all the faculties ... and all the affections and sympathies ... are alike essential'. ${ }^{49}$ Having connected taste with morality, she is anxious to imagine that it is something that can be possessed by as many people as possible.

However, Archibald Alison's account potentially allowed for a descent into the sort of relativism Reid and the common sense philosophers disliked - based on the random associations made by the individual, taste might become merely a matter of personal opinion. In contrast, Elizabeth Hamilton's common sense background led her to insist that, in taste, as well as in other matters, there were correct conclusions to be reached. Hamilton, like Campbell, insists on the common environmental influences that form our associations in childhood and which affect everyone's tastes. Discussing the 'recollection' which triggers the emotions of taste, she selects an association, light, which almost everyone must share, and which promotes 'cheerful' ideas. ${ }^{50}$ She argues that light produces cheerfulness because it is associated with the first consciousness of existence; she recalls the infants 'delight' in seeing 'luminous objects' and so first learning 'the art of seeing. ${ }^{51}$ With this account of childhood, Hamilton, as David Hartley had done, indicates how general environmental influences educate our taste, and, importantly, she lays the foundations of a taste which, although working on personal emotional associations, is similar in all human beings. ${ }^{52}$

Elizabeth Hamilton also suggests how this pattern of environmental associations produces a moral effect. When an external object reminds an observer of a noble quality or tender feeling, he or she feels the emotions of taste. As Alison put it: 
Not only the smell of the Rose, or the Violet, is expressed to us by their Colours and Forms; but the utility of a Machine, the elegance of a Design, the proportion of a Column, the Speed of the Horse, the ferocity of the Lion, even all the qualities of the human mind, are naturally expressed to us by certain visible appearances; because our experience has taught us, that such qualities are connected with such appearances. ... Such visible qualities, therefore, are gradually considered as the Signs of other qualities, and are productive to us of the same Emotions with the qualities they signify. ${ }^{53}$

Unlike Alison, Hamilton is interested in qualities of the human heart than those of the mind. Like Wordsworth's 'feeling', her anthropomorphizing taste fills the observer with 'the same affections as are inspired by the proper objects of his love' and ensures that he will have an enhanced moral sense towards his family. In turn, his developed responsibility leads to him only buying those objects which are tasteful because genuinely useful. As Hamilton expresses it, 'ideas of utility, or of propriety, fitness, symmetry, and congruity' are connected to taste - the tasteful person (who is, in her account, necessarily considerate) reflects upon the actual benefits an object will confer. ${ }^{54}$ Avoiding the mental dependence caused by following the latest trend, he will become a responsible member of the community, which should have similar values.

As this emphasis on shared values suggests, Hamilton's attempt to overcome the problems of a more inclusive account of taste rewrites Hume. Hume's emphasis on the role of the imagination, mentioned earlier, led him to worry about the possible erosion of individual opinion. Hamilton's common sense confidence in being able to arrive at truths concerning the external world, on the other hand, meant that, unlike Hume in his more pessimistic moments, she saw an alternative to the continual attrition of personal belief and opinion. While aware that sympathy may produce prejudice, she had confidence in an educational system which exercises 'the attention' 'in acquiring clear and distinct ideas'; such an education would allow the individual to develop his own opinions, which would then in most cases coincide with those of other people..$^{55}$ Less worried by the erosion of self by other, Hamilton is able to select affective criteria as the correct ones by which to make judgements of taste, in the process rejecting elitist learning as a basis for the standard.$^{56}$ Unlike Hume's critic in 'Of the Standard of Taste', her critic makes comparisons, not between different artworks, but between feelings. A potentially more inclusive basis for taste is established, relying on the rejection of high status - and therefore fashionable - objet d'art in favour of a more precise set of 
emotional and ethical associations gained through the environment.

Elizabeth Hamilton provides one of the clearest examples of the rejection of the supposed misplaced associations of fashion for the accurate emotional associations produced by the environment. However, this trend is also traceable in the work of her friend, Joanna Baillie, and in William Wordsworth's 1802 preface to the Lyrical Ballads. Exhibiting the contemporary anxiety with fashion (an anxiety increased by the post-French Revolution debate), all three writers opposed the fashionable to the more tasteful 'natural' - by Baillie defined as the indigenous and the common. In each case, the opposition to fashion is constructed through a common sense adaptation of association of ideas; an examination of human emotion in some area where it is supposedly represented accurately (the drama, the countryside) develops a tasteful set of associations and enables accurate and supposedly more permanent conclusions to be drawn about the world.

Understanding the influence of Scottish common sense philosophy upon Hamilton sheds valuable light on these characteristic aesthetic divisions of Romanticism. Her work makes it evident that the rejection of fashion stems from the implication of the notion of fashion in the philosophical and political conflict of the 1790s. Hamilton employed the common sense criticisms of scepticism against radical philosophy, taking Hume's work on the imagination and arguing that it is the radicals who are overly imaginative. Adapting the radical rhetoric on the dangers of fashion, Hamilton argues that, like women and soldiers, 'metaphysicians' are subject to the random associations of fashion. In reaction, she attempts to arrive at an alternative, a more accurate mode of aesthetic judgement. Based on the common sense proposal that it is possible to arrive at accurate judgements which have reference to an external 'true' state of affairs, Hamilton posits a mode of taste which is available to anyone willing to give attention to their environment. In its common sense reliance on building accurate associations from observation of the external world, it also provides some philosophical basis for the (supposedly) more permanent or natural associations favoured by Wordsworth and Baillie. In this account, instead of following fashion, individuals could build their taste on associations given by their environment and, since these would be similar, expect to reach some agreement over matters of aesthetic judgement. Finally, the radical potential of this approach to taste should not be forgotten. Common sense philosophy posited a version of a tastefulness which insisted that taste should no longer be the signal of the upper ranks' political superiority. For Hamilton, in particular, the common sense position that it is possible to reach accurate judgements about the external 
world opens correct aesthetic judgement to everyone. Indeed, in her narrative it is imperative that individuals strive for accurate observation and judgement - if they don't, society might be led en masse into the mistaken associations characteristic of scepticism, atheism and revolution. Hamilton's new aesthetic is based on the belief that for society to remain safe, it is not enough for only the few to be capable of

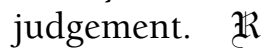

University College Chichester

\section{Notes}

1. See David Simpson, Romanticism, Nationalism, and the Revolt against Theory (Chicago, IL: University of Chicago Press, 1993); or Marilyn Butler, 'Irish Culture and Scottish Enlightenment: Maria Edgeworth's Histories of the Future', Economy, Polity, and Society: British Intellectual History 1750-1950, ed. by Stefan Collini, Richard Whatmore and Brian Young (Cambridge: Cambridge University Press, 2000), pp. 158-80.

2. William Wordsworth and Samuel Taylor Coleridge, Lyrical Ballads, ed. by R.L. Brett and A.R. Jones, 2nd edn (London: Routledge, 1991), pp. 241-72; subsequently Wordsworth, Lyrical Ballads.

3. Wordsworth, Lyrical Ballads, p. 249.

4. Marilyn Butler, Jane Austen and the War of Ideas (1975; Oxford: Clarendon Press, 1987), p. 6. For a discussion of the use of 'quixote' see David Duff, Romance and Revolution: Shelley and the Politics of a Genre (Cambridge: Cambridge University Press, 1993).

5. Gary Kelly, 'Jane Austen and the 1790s', Fetter'd or Free? British Women Novelists 1670-1815, ed. by Mary Anne Schofield and Cecilia Macheski (Athens, OH: Ohio University Press, 1986), pp. 285-306, p. 289.

6. This reluctance to examine the philosophical background of conservatism is the case even in a study as ambitious as Gary Kelly's Women, Writing and Revolution (Oxford: Clarendon Press, 1993).

7. See David Simpson, Romanticism, Nationalism, and the Revolt against Theory.

8. Julie Choi, 'Feminine Authority? Common Sense and the Question of Voice in the Novel', New Literary History, 27 (1996), pp. 641-62; see in particular pp. 643-5.

9. See, for example, Mary Wollstonecraft's A Vindication of the Rights of Men where she attacks Burke's reliance on tradition and precedent: 'that we are to reverence the rust of antiquity, and term the unnatural customs, which ignorance and mistaken self-interest have consolidated, the sage fruit of experience: nay, that, if we do discover some errors, our feelings should lead us to excuse, with blind love, or unprincipled filial affection, the venerable vestiges of ancient days. These are gothic notions of beauty - the ivy is beautiful, but, when it insidiously destroys the trunk from which it receives support, who would not grub it up?' Political Writings: A Vindication of the Rights of Men: A Vindication of the Rights of Woman: An Historical and Moral View of the French Revolution (Oxford: World's Classics Oxford University Press, 1994), p. 8.

10. Elizabeth Hamilton, The Cottagers of Glenburnie; A Tale for the Farmer's Ingle-Nook (Edinburgh: Ballantyne for Manners and Miller, and Cheyne; London: Cadell and Davies, and Miller, 1808); subsequently Cottagers, and A Series of Popular Essays, Illustrative of Principles Essentially Connected with the Improvement of the Understanding, the Imagination, 
and the Heart (1813), 2nd edn, 2 vols (Edinburgh: Manners and Miller; London: Longman, Hurst, Rees, Orme, and Brown and Cadell and Davies, 1815); subsequently Popular Essays. 11. See Thomas Reid, An Inquiry into the Human Mind, on the Principles of Common Sense (1764), ed. by Timothy J. Duggan (Chicago, IL: University of Chicago Press, 1970), 'Dedication', p. v; subsequently cited as Reid.

12. Reid, 'Dedication', p. vi.

13. Reid, 'Dedication', p. iii.

14. For an account of discussions of association see Martin Kallich, The Association of Ideas and Critical Theory in Eighteenth-Century England: A History of the Psychological Method in English Criticism (The Hague: Mouton, 1970).

15. See, for example, David Hume, A Treatise of Human Nature, ed. by L.A. Selby-Bigge, 2nd edn, rev by P.H. Nidditch (Oxford: Clarendon Press, 1978), particularly I, III, XII, pp. 130-42, 'Of the Probability of Causes'.

16. David Hume, 'Of the Standard of Taste', Essays Moral, Political and Literary (1777), ed. by Eugene F. Miller, revised edn (Indianapolis: Liberty Classics, 1985), pp. 226-49.

17. Hume, Essays, pp. 237-9.

18. David Hume, 'Of the Rise and Progress of the Arts and Sciences', Essays, p. 120.

19. George Campbell, The Philosophy of Rhetoric (London: Strahan and Cadell; Edinburgh: Creech, 1776), 2 vols; see in particular I, V, II, I, p. 43 and I, V, II, I, p. 47; subsequently Campbell.

20. Campbell, part I, 43, part II, 48.

21. Campbell, part II, 49.

22. Elizabeth Hamilton, Translation of the Letters of a Hindoo Rajah, ed. by Pamela Perkins and Shannon Russell (Peterborough, ON: Broadview Press, 1999); subsequently Translation.

23. Hamilton, Translation, p. 257.

24. Hamilton, Translation, p. 266.

25. Eliza[beth] Hamilton, letter to Mary Hays, 13 March 1797, RP677, Department of Manuscripts, British Library, London.

26. See Mary Wollstonecraft, Political Writings: in A Vindication of the Rights of Woman. Wollstonecraft had argued that in a standing army: 'A spirit inspired by romantic notions of honour, a kind of morality founded on the fashion of the age, can only be felt by a few officers, whilst the main body must be moved by command, like the waves of the sea; for the strong wind of authority pushes the crowd of subalterns forward, they scarcely know or care why, with headlong fury' (Political Writings, p. 81; my italics).

27. Elizabeth Hamilton, Memoirs of Modern Philosophers, ed. by Claire Grogan (Peterborough, ON: Broadview Press, 2000), p. 57; subsequently Memoirs.

28. Hamilton, Memoirs, pp. 38-40.

29. William Godwin, Enquiry Concerning Political Justice and Its Influence on Morals and Happiness, 1793, ed. by F.E.L. Priestley, 3 vols (Toronto: University of Toronto Press, 1946); Mary Hays, Memoirs of Emma Courtney (1796), ed. by Eleanor Ty (Oxford: Oxford World Classics - Oxford University Press, 1996).

30. Elizabeth Hamilton, Letters on Education (Bath: Crutwell for Robinson, 1801); also published as Letters on the Elementary Principles of Education, 2nd edn, 2 vols (Bath: Crutwell for Robinson, 1801), p. v; subsequently L. on E.

31. Hamilton, L. on E., pp. vi-vii.

32. Wordsworth, Lyrical Ballads, p. 241.

33. Daniel Cottom, The Civilized Imagination: A Study of Ann Radcliffe, Jane Austen, and 


\section{Romanticism}

Sir Walter Scott (Cambridge: Cambridge University Press, 1985), p. 3.

34. Sir Joshua Reynolds, Discourses on Art (1797), ed. by Robert R. Wark (New Haven, CT: Yale University Press, 1997), p. 70.

35. Cottom, The Civilized Imagination, p. 11.

36. See Elizabeth Benger, Memoirs of the late Mrs Elizabeth Hamilton, 2 vols (London: Longman, 1818), I, p. 50.

37. Wordsworth, Lyrical Ballads, p. 245.

38. Mary Wollstonecraft, The Works of Mary Wollstonecraft, ed. by Janet Todd and Marilyn Butler, 7 vols (London: Pickering, 1989), IV, p. 7.

39. Hamilton, Cottagers, p. 140.

40. Hamilton, Cottagers, p. 145.

41. Hamilton, Cottagers, p. 146.

42. Hamilton, Cottagers, pp. 397-8.

43. Hamilton, Cottagers, p. 18.

44. Hamilton, Cottagers, p. 392.

45. Hamilton, Cottagers, p. 194.

46. Wordsworth, Lyrical Ballads, p. 249.

47. Archibald Alison, Essays on the Nature and Principles of Taste (1790), 5th edn, 2 vols (Edinburgh: Willison for Constable; London: Longman, Hurst, Rees, Orme and Brown, 1817).

48. Hamilton, Popular Essays, I, p. 186.

49. Hamilton, Popular Essays, I, pp. 184-5; see also Letters on Education, pp. 3, 10.

50. Hamilton, Popular Essays, I, p. 187.

51. Popular Essays, I, p. 187; a similar point is made by Dugald Stewart in Philosophical Essays, ed. by Sir William Hamilton (Edinburgh: Constable; London: Hamilton, Adams, 1855), vol. 5 of The Collected Works of Dugald Stewart, esq., F.R.S.S., 11 vols. See part 2 (Philosophical Essays, p. 204; 2. 2.1.2).

52. See David Hartley, Observations on Man, His Frame, His Duty, and His Expectations (1749), introduction by Theodore L. Huguelet (Gainesville, FL: Scholars' Facsimiles, 1966), pp. 418-42: 1. iv. 1.

53. Alison, I, pp. 291-2.

54. Hamilton, Popular Essays, p. 232.

55. Hamilton, L. on E., p. 346.

56. Hamilton, Popular Essays, I, p. 235.

57. Joanna Baillie, A Series of Plays (1798), Revolution and Romanticism, 1789-1834, ed. by Jonathan Wordsworth (Oxford: Woodstock, 1990), p. 20. 